\title{
Pathogenesis of Thalassemia Major-associated Osteoporosis: A Review with Insights from Clinical Experience
}

\author{
(1) Agostino Gaudio1, (1) Nancy Morabito22, (1) Antonino Catalano², (1) Rosario Rapisarda1', (1) Anastasia Xourafa1, (1) Antonino Lasco² \\ 1 University of Catania, Department of Clinical and Experimental Medicine, Catania, Italy \\ 2University of Messina, Department of Clinical and Experimental Medicine, Messina, Italy
}

\begin{abstract}
Due to increasing life expectancy in thalassemia major (TM), osteoporosis is emerging as a significant problem. Its aetiology is multifactorial, culminating in increased bone resorption and impaired remodelling. Hypogonadism and marrow expansion seem to play an important role, but iron overload, deferoxamine toxicity, a defective growth hormone-insulin-like growth factor-1 axis and multiple endocrinopathies may represent additional causes of bone damage. Many of these patients, though under appropriate treatment programs, do not achieve normal peak bone mass. The receptor activator of nuclear factor kappa-B (RANK)/RANK ligand/osteoprotegerin and the Wnt/ $/$-catenin systems work as major mediators of imbalanced bone turnover and bone loss. Additional genetic factors, such as collagen type 1 alpha 1 and vitamin D receptor gene polymorphisms, may exert some influence on the enhanced fracture risk observed in TM. To date, in spite of adequate hormone replacement, chelating therapy and acceptable haemoglobin levels, subjects with TM display impaired bone density and imbalanced bone turnover, thus the puzzle of the pathogenesis of TM-induced osteoporosis remains far from being solved.
\end{abstract}

Keywords: Osteoporosis, thalassemia major, hypogonadism, marrow expansion, bone turnover

\section{Introduction}

Thalassemia major (TM) is a hereditary disease caused by defective globin synthesis, resulting in abnormal as well as a decreased quantity of globin chains, ineffective erythropoiesis, haemolysis and increased red blood cell turnover. Cooley et al (1) described the first patients with anaemia, splenomegaly and cranial and facial bone enlargement. These bone changes were due to the marked expansion of the bone marrow, secondary to anaemia and ineffective erythropoiesis $(2,3)$. Although optimised blood transfusions and iron chelation programs have greatly increased the life expectancy of TM patients and prevented these severe bone alterations, osteoporosis and osteopenia remain serious complications, even in well-transfused and well-iron chelated patients (4).

The pathogenesis of bone changes in TM is not fully clarified. Several studies have shown that multiple factors may act in concert to produce bone disease in TM including bone marrow expansion (5), hypogonadism (6,7,8), defective growth hormone-insulin-like growth factor-1 (GH-IGF-1) axis $(9,10,11,12)$, altered pattern of cytokines (13), iron deposit in bone $(5,14,15)$, deferoxamine bone toxicity $(16,17)$ and vitamin D deficiency (18). Some of these pathogenic factors, directly and/or indirectly, affect osteoblastic population, leading to depressed bone formation, while others often increase osteoclastic bone resorption.

In this review, in the light of our experience, we analysed the alterations of bone metabolism and the acquired and genetic factors that could be responsible for the development of osteopenia/osteoporosis in TM patients.

\section{Bone Metabolism in TM Patients}

Osteoporosis is a skeletal disorder characterized by compromised bone strength, predisposing to an increased risk of fracture (19). According to the World Health Organization, diagnosis of osteoporosis is based on the T-score for bone mineral density (BMD), assessed at the lumbar spine or the femoral neck. Osteoporosis is defined 
by a BMD that is 2.5 standard deviations (SD) or more below the mean value for a young adult female (T-score less than or equal to $-2.5 \mathrm{SD}$ ) (20). The Z-score describes the number of SDs by which the BMD in an individual differs from the mean value expected for a given age and sex. The diagnosis of osteoporosis in children and adolescents should not be made on the basis of densitometric criteria alone. In the absence of vertebral compression (crush) fractures, the diagnosis of osteoporosis is indicated by the presence of both a clinically significant fracture history and BMD Z-score less than or equal to $-2.0 \mathrm{SD}$ (21). In some studies $(22,23)$, in order to reduce the influence of bone size on BMD measurements in the growing skeleton, the apparent volumetric density of the lumbar spine has been calculated using a specific formula (24).

In TM patients, it is very common to find low BMD values (osteopenia or osteoporosis) and in some studies up to $90 \%$, even in optimally transfused and chelated patients, as is shown in Table $1(8,25,26,27,28,29,30)$.

Prevalence of fractures in TM patients is depicted in Table 2 and ranges from $16 \%$ to $49 \%$, depending on study population and method of data collection $(3,31,32,33,34,35)$.
Extremity fractures are the most common (26), in particular at the upper extremity (31). Vertebral fractures are usually underestimated, and their prevalence varies from $2.6 \%$ to $13 \%(26,36)$.

TM patients, in spite of following a regular transfusional regimen, and receiving adequate sex hormone replacement and chelating therapy, show imbalanced bone turnover with an increased resorptive phase that is not followed by an appropriate neoformation rate, resulting in a decreased BMD, particularly at the vertebral level, where trabecular bone is mostly represented $(22,26,37,38,39)$. In previous studies (12,22), we described a decreased neoformation phase in accordance with Mahachoklertwattana et al (23) and histomorphometric studies performed by De Vernejoul et al (40).

The depression of bone formation, even if slight, is surprising because an increase in resorption is generally followed by a corresponding increase in bone formation due to coupling of bone turnover. Numerous acquired factors could lead to the inhibition of osteoblastic activity, such as a defective GH-IGF-1 axis, iron deposits in bone, or deferoxamine toxicity $(12,22)$. Many studies $(12,22,37,38,41,42)$ have

\begin{tabular}{|c|c|c|c|c|c|c|}
\hline Study & $\begin{array}{l}\text { Subjects } \\
\text { (n) }\end{array}$ & Gender & $\begin{array}{l}\text { Mean age } \\
\text { (year) }\end{array}$ & Osteoporosis (\%) & Osteopenia (\%) & $\begin{array}{l}\text { Criteria for diagnosis of } \\
\text { osteoporosis }\end{array}$ \\
\hline Vogiatzi et al (26) & 236 & $\begin{array}{l}116 \text { males } \\
120 \text { females }\end{array}$ & 24.4 & $49.1 \%$ & $30.5 \%$ & $\begin{array}{l}\text { Osteopenia: Z-score } \\
\text { between -1 and -2 SD } \\
\text { Osteoporosis: Z-score below } \\
\text { - } 2 \text { SD }\end{array}$ \\
\hline Aslan et al (28) & 47 & $\begin{array}{l}25 \text { males } \\
22 \text { females }\end{array}$ & NA & $53.1 \%$ & $44.6 \%$ & $\begin{array}{l}\text { Osteopenia: Z-score } \\
\text { between - } 1 \text { and }-2.5 \mathrm{SD} \\
\text { Osteoporosis: Z-score below } \\
-2.5 \mathrm{SD}\end{array}$ \\
\hline Izadyar et al (29) & 40 & $\begin{array}{l}21 \text { males } \\
19 \text { females }\end{array}$ & 23.0 & $\begin{array}{l}12.5 \% \\
\text { (femoral level) } \\
37.5 \% \\
\text { (lumbar level) }\end{array}$ & $\begin{array}{l}37.5 \% \\
\text { (femoral level) } \\
47.5 \% \\
\text { (lumbar level) }\end{array}$ & $\begin{array}{l}\text { Osteopenia: Z-score } \\
\text { between - } 1 \text { and }-2.5 \text { SD } \\
\text { Osteoporosis: Z-score below } \\
-2.5 \text { SD }\end{array}$ \\
\hline Tzoulis et al (30) & 99 & $\begin{array}{l}49 \text { males } \\
50 \text { females }\end{array}$ & 36 & $55.5 \%$ & NA & $\begin{array}{l}\text { Osteoporosis: Z-score below } \\
-2 \mathrm{SD}\end{array}$ \\
\hline
\end{tabular}

NA: not available, SD: standard deviation 
shown increased osteoclast activation in these patients, measuring markers of bone resorption such as urinary levels of N-telopeptide of collagen type 1, serum levels of tartrate resistant acid phosphatase isoform-5b, and urinary pyridinium cross-links. The mechanism responsible for this osteoclast activation in well-treated thalassemic patients could be related to the altered cytokines network, which is often observed in these patients.

\section{Cytokines Network}

The receptor activator of nuclear factor kappa-B (RANK)/ RANK ligand (RANKL)/osteoprotegerin (OPG) system regulates the activation and proliferation of osteoclast precursors (43). In our previous study (42), and in accordance with others (41), we found that the ratio of RANKL/OPG is increased in patients with TM and osteoporosis, showing that the RANKL/OPG system acts as an important paracrine mediator of bone metabolism also in TM patients. Cytokines other than RANKL and OPG, such as interleukin (IL)- $1 \alpha$, IL-6 and tumor necrosis factor- $\alpha$, that are largely recognised as important effectors in the pathogenesis of several forms of osteoporosis $(44,45,46,47)$, could have a role in TM-related osteoporosis. Our data (13) clearly showed an increase of circulating pro-osteoclastogenic cytokines associated with several markers of bone turnover and densitometric data, also pointing to their potential role in accelerating bone loss in TM-related osteoporosis. In particular, we observed significantly higher serum concentrations of $\mathrm{IL}-1 \alpha$ and IL-6 in TM patients and a significant correlation of these cytokines with urinary pyridinium cross-links (13).

Recently, the Wnt/ $\beta$-catenin canonical pathway has been suggested to be involved in bone remodelling by promoting proliferation and differentiation of osteoblast precursor

Table 2. Fracture prevalence in thalassemia major patients

\begin{tabular}{|c|c|c|c|c|}
\hline Study & Subjects (n) & Gender & Mean age (year) & Fracture prevalence (\%) \\
\hline Exarchou et al (32) & 62 & $\begin{array}{l}36 \text { males } \\
26 \text { females }\end{array}$ & 16.7 & $32.2 \%$ \\
\hline Finsterbush et al (33) & 61 & $\begin{array}{l}30 \text { males } \\
31 \text { females }\end{array}$ & 16.0 & $49.1 \%$ \\
\hline Ruggiero and De Sanctis (3) & 977 & $\begin{array}{l}472 \text { males } \\
505 \text { females }\end{array}$ & NA & $19.7 \%$ \\
\hline Vogiatzi et al (34) & 379 & $\begin{array}{l}177 \text { males } \\
202 \text { females }\end{array}$ & 20.2 & $16.6 \%$ \\
\hline Fung et al (31) & 152 & $\begin{array}{l}80 \text { males } \\
72 \text { females }\end{array}$ & 25.5 & $38.8 \%$ \\
\hline Sutipornpalangkul et al (35) & 136 & $\begin{array}{l}48 \text { males } \\
88 \text { females }\end{array}$ & 30.8 & $44.1 \%$ \\
\hline
\end{tabular}

cells, reducing apoptosis of mature osteoblasts, and promoting the ability of differentiated osteoblasts to inhibit osteoclast differentiation. This pathway has been proposed to participate in the pathogenesis of osteoporosis in TM, and negative modulators of this signalling system, such as Dickkopf-1 and sclerostin, have also been associated with BMD in TM patients $(48,49)$.

\section{Bone Marrow Expansion}

Bone marrow expansion $(2,3,4,50)$ is considered by various authors as a major determinant of bone destruction in TM patients. In spite of regular blood transfusions, the ineffective erythropoiesis in TM is not fully suppressed. Expansion of the bone marrow may contribute to the decreased BMD - even if data are contradictory (51) - because transferrin receptor studies have demonstrated increased bone marrow activity, even in patients with low reticulocyte count or marrow hypoplasia (52).

An intimate relationship between bone marrow and the process of remodelling exists, however. This interaction between bone marrow and bone tissue could explain the fact that bone loss in TM largely involves trabecular bone. In fact, the lumbar spine, which consists mostly of trabecular bone and with wide bone marrow spaces, is the most affected site in these patients (23).

It has been speculated that the increased generation of cells of the erythropoietic lineage may adversely affect the proliferation and maturation of cells of the osteogenic lineage. Osteoclasts originate from a hemopoietic granulocyte-macrophage lineage. The cytokines that are involved in haematopoiesis are also involved in the development of osteoclasts (53). Therefore, it is possible that the mechanism that stimulates haematopoiesis in TM 
may also stimulate osteoclastic formation and/or activity, which, in turn, increases bone resorption and reduces bone mass.

\section{Iron Overload in Endocrine Glands}

A regular transfusional regimen is a cornerstone of TM treatment, but theis results in significant iron overload. Excessive iron is deposited in almost all tissues but primarily in the liver, the heart and the endocrine glands. Early introduction of a chelating agent to prevent iron overload in vulnerable organs leads to improved life expectancy (54).

TM patients often present with multiple endocrine dysfunctions including growth failure, hypogonadism, diabetes, hypothyroidism, hypoparathyroidism and, less frequently, hypoadrenalism $(5,55,56,57)$. Several authors demonstrated that these abnormalities were closely related to iron overload, as shown by histological findings in different endocrine glands (58). Shamshirsaz et al (5), analysing $220 \mathrm{TM}$ patients, found significant differences in mean serum ferritin levels between TM patients affected by primary amenorrhea and hypogonadism and TM patients without endocrinopathies. Moreover, the authors observed that impaired puberty was the most common endocrine abnormality (over $70 \%$ of the participants). The prevalence of other endocrinopathies was much lower with $17.5 \%$ hypogonadism, $8.7 \%$ diabetes mellitus, $7.7 \%$ primary hypothyroidism and $7.6 \%$ hypoparathyroidism. De Sanctis et al (55), analysed 1861 patients and reported slightly different data. In particular, failure of puberty was the major clinical endocrine defect and was present in $51 \%$ of boys and $47 \%$ of girls, all over the age of 15 years. Secondary amenorrhoea was recorded in $23 \%$ of patients, primary hypothyroidism in $6.2 \%$, insulin dependent diabetes mellitus in $4.9 \%$ and hypoparathyroidism in $3.6 \%$ of the patients.

\section{Hypogonadism}

Although data on prevalence are discordant, as reported above, TM patients often show gonadal impairment (6). Haemosiderosis of the pituitary gonadotrophic cells and iron deposition in the testes and ovaries are involved in the pathogenesis of hypogonadism in TM $(59,60)$. In addition hypogonadism is a well-recognised cause of osteoporosis and osteopenia, not only in TM, but also in the general population $(61,62,63)$.

In our previous study (22), in accordance with Anapliotou et al (6) and Jensen et al (8), we showed that hypogonadism produces more severe bone loss in TM. Our group had already shown that TM patients complained of various degrees of osteopenia due to their hormonal status. In fact, we observed that in TM patients without evidence of hypogonadism because of hormone replacement therapy, bone status was less compromised and osteoporosis was observed only at the lumbar site, where the influence of bone marrow expansion is prominent, as described above. However, in hypogonadic patients, osteoporosis may be more severe and may also affect the femoral site. Furthermore, we found a significant positive correlation between BMD values and hormonal treatment duration.

\section{GH-IGF-1 Axis}

Several studies showed that the GH-IGF-1 axis is altered in TM patients $(11,12)$. These patients have significantly lower circulating levels of IGF-1 and the corresponding binding protein (IGFBP-3) than normal individuals $(11,12)$. IGF-1 plays an important role in bone remodelling. Low serum IGF levels decrease osteoblast proliferation and bone matrix formation and reduce the activation of osteoclasts (64). A positive correlation between BMD at the lumbar spine and IGF-1 concentration has been reported $(48,65)$. In our previous work (12), we found lower serum levels of IGF-1 and IGFBP-3 in TM patients than in age-matched, healthy controls and a significant correlation between IGF1 , osteocalcin which is a marker of bone formation, and BMD values. Similarly, low concentrations of IGF-1 in TM adults and their correlation with BMD have been reported by Dresner Pollak et al (37).

The mechanisms responsible for the reduced action of the IGF-1/IGFBP-3 axis in TM are still being debated. Danesi et al (66) found an impairment of GH secretion in a considerable proportion of TM patients, compatible with hypothalamic and/or pituitary damage. It is unclear whether the IGF-1 level decreases before or after $\mathrm{GH}$ secretion dysfunction $(67,68,69)$. Chrysis et al $(70)$ suggested that impaired GH secretion, rather than GH insensitivity, is the cause of growth retardation in TM patients.

\section{Iron Deposition in Bone}

Iron deposition in bone damages osteoid maturation and inhibits mineralisation, resulting in focal osteomalacia. This is due to the incorporation of iron into crystals of calcium hydroxyapatite, which consequently affects the growth of hydroxyapatite crystals and reduces basic multicellular unit tensile strength (71). Mahachoklertwattana et al (23) observed increased osteoid thickness, osteoid maturation time and mineralisation lag time in TM patients. 


\section{Deferoxamine}

Subcutaneously administered deferoxamine was for a long time the treatment of choice for iron overload in TM. Its chelating action is not solely specific for iron. Deferoxamine also inhibits DNA synthesis, collagen formation and osteoblast precursor differentiation and enhances osteoblast apoptosis $(16,17)$. Data on bone safety of new oral chelating agents are still limited.

\section{Vitamin D}

Vitamin D deficiency is involved in the pathogenesis of osteoporosis in TM patients due to its regulatory effects on bone cells and calcium homeostasis. Lower 25-hydroxyvitamin D levels, in comparison to healthy controls, are a common finding and are inversely correlated with ferritin levels and age. Lower sun exposure due to reduced physical activity and defective skin synthesis associated with jaundice are probably responsible for this deficiency (72).

\section{Genetic Factors}

Genetic factors also have an important role in determining BMD in TM patients, although the genes responsible are poorly defined in this population. Some studies provide partially support for an association between BMD and specific COL1A1 (73) and TGF- $\beta 1$ (74) gene polymorphism in TM. Vitamin D receptor (VDR) polymorphisms could also represent a risk factor for low BMD in adult TM patients $(37,75)$. In our thalassemic population, we found that VDR (FokI, BsmI) and COL1A1 (Sp1) gene polymorphisms had no influence on BMD, but BsmI was found to display beneficial effects on patient response to alendronate therapy (76). It has recently been reported that the $\mathrm{f}$ allele of the Fok-I gene polymorphism, when found in homozygosity, confers protection on the BMD values of young thalassemic patients (77).

\section{Conclusion}

Multiple acquired factors, together with genetic variants that predispose individuals to reduced BMD, contribute to bone fragility in TM. Bone marrow expansion, hypogonadism, a defective GH-IGF-1 axis and imbalanced cytokine profiles play major roles in the development of osteoporosis. Iron overload, deferoxamine toxicity and other endocrine dysfunctions could be additional factors. Figures 1 and 2 summarise potential factors contributing to the imbalanced bone turnover in TM patients. To date, in spite of adequate hormone replacement therapy, acceptable haemoglobin levels and chelating therapy, TM patients unexpectedly display impaired BMD and imbalanced bone turnover, indicating that the puzzle of the pathogenesis of TM-related osteoporosis is still far from being fully solved.

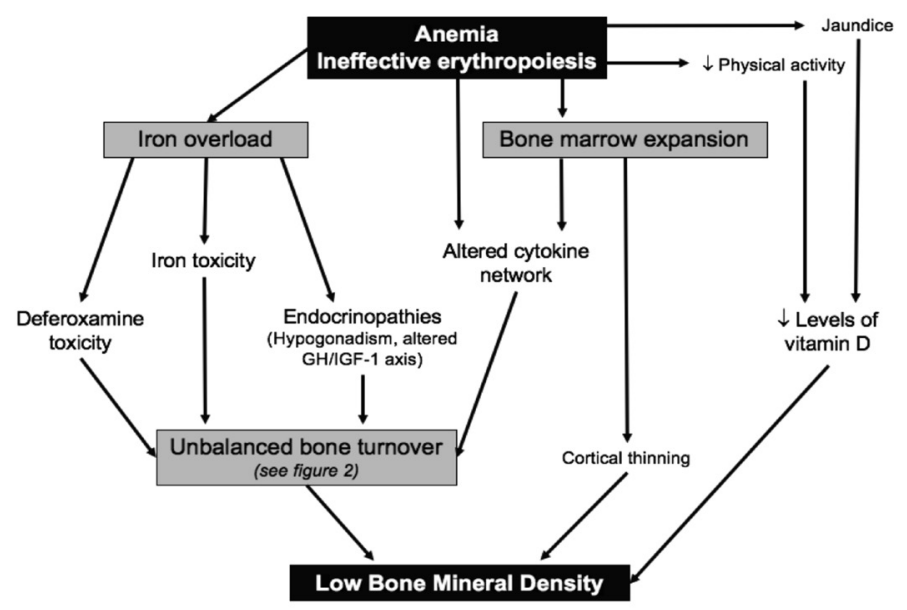

Figure 1. Pathogenesis of low bone mineral density in thalassemic patients

GH-IGF-1: growth hormone-insulin-like growth factor-1

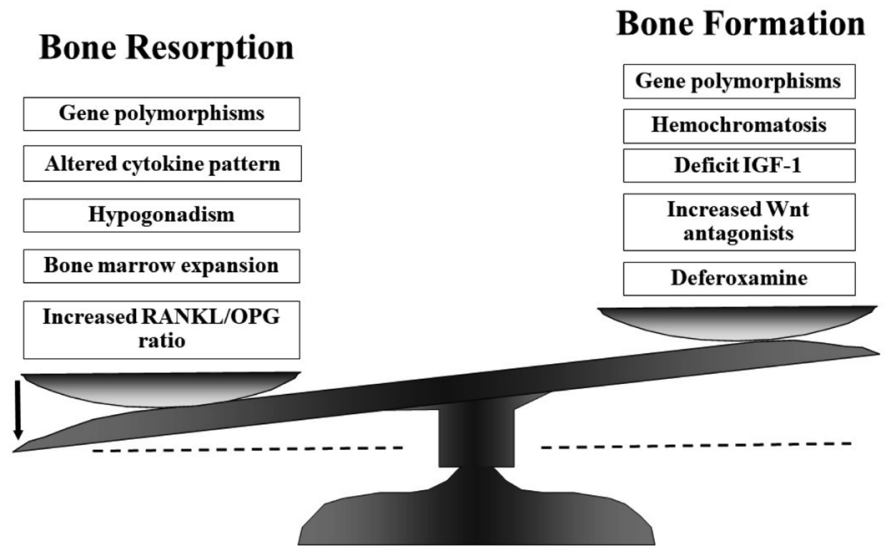

Figure 2. Possible causes for uncoupling bone turnover in thalassemic patients

IGF-1: insulin-like growth factor-1, RANKL/OPG: receptor activator of nuclear factor kappa-ß/osteoprotegerin

\section{Ethics}

Peer-review: Externally peer-reviewed.

\section{Authorship Contributions}

Concept: Agostino Gaudio, Nancy Morabito, Design: Nancy Morabito, Antonino Lasco, Data Collection and Processing: Antonino Catalano, Anastasia Xourafa, Analysis and Interpretation: Agostino Gaudio, Nancy Morabito, Literature Research: Agostino Gaudio, Antonino Catalano, Rosario Rapisarda, Writing: Agostino Gaudio, Nancy Morabito, Antonino Catalano. 
Financial Disclosure: The authors declared that this study received no financial support.

\section{References}

1. Cooley TB, Witwer ER, Lee P. Anemia in children with splenomegaly and peculiar changes in bones report of cases. Am J Dis Child 1927;34:347-363.

2. Pootrakul P, Hungsprenges S, Fucharoen S, Baylink D, Thompson E, English E, Lee M, Burnell J, Finch C. Relation between erythropoiesis and bone metabolism in thalassemia. N Engl J Med 1981;304:14701473.

3. Ruggiero L, De Sanctis V. Multicentre study on prevalence of fractures in transfusion dependent thalassemic patients. J Pediatr Endocrinol Metab 1998;11:773-778.

4. Poggi M, Sorrentino F, Pugliese P, Smacchia MP, Daniele C, Equitani F Terlizzi F, Guitarrini MR, Monti S, Maffei L, Losardo A, Pasin M, Toscano $\mathrm{V}$. Longitudinal changes of endocrine and bone disease in adults with $\beta$-thalassemia major receiving different iron chelators over 5 years. Ann Hematol 2016;95:757-763.

5. Shamshirsaz AA, Bekheirnia MR, Kamgar M, Pourzahedgilani N, Bouzari N, Habibzadeh M, Hashemi R, Shamshirsaz AA, Aghakhani S, Homayoun H, Larijani B. Metabolic and endocrinologic complications in beta-thalassemia major: a multicenter study in Tehran. BMC Endocr Disord 2003:3:4

6. Anapliotou ML, Kastanias IT, Psara P, Evangelou EA, Liparaki M, Dimitriou P. The contribution of hypogonadism to the development of osteoporosis in thalassemia major: new therapeutic approaches. Clin Endocrinol (Oxf). 1995;42:279-287

7. Saka N, Sükür M, Bundak R, Anak S, Neyzi O, Gedikoğlu G. Growth and puberty in thalassemia major. J Pediatr Endocrinol Metab 1995;8:181. 186

8. Jensen CE, Tuck SM, Agnew JE, Koneru S, Morris RW, Yardumian A, Prescott E, Hoffbrand AV, Wonke B. High prevalence of low bone mass in thalassaemia major. Br J Haematol 1998;103:911-915.

9. Soliman AT, El Banna N, Abdel Fattah M, El Zalabani MM, Ansari BM Bone mineral density in prepubertal children with $\beta$-thalassemia: correlation with growth and hormonal data. Metabolism 1998;47:541 548

10. Scacchi M, Danesi L, Cattaneo A, Valassi E, Pecori Giraldi F, Argento C, D’Angelo E, Mirra N, Carnelli V, Zanaboni L, Tampieri B, Cappellin $\mathrm{MD}$, Cavagnini F. Bone demineralization in adult thalassaemic patients: contribution of GH and IGF-I at different skeletal sites. Clin Endocrinol (Oxf) 2008;69:202-207.

11. Soliman AT, El Banna N, Ansari BM. GH response to provocation and circulating IGF-I and IGF-binding protein-3 concentrations, the IGF-I generation test and clinical response to GH therapy in children with beta-thalassaemia. Eur J Endocrinol 1998;138:394-400.

12. Lasco A, Morabito N, Gaudio A, Crisafulli A, Meo A, Denuzzo G, Frisina N. Osteoporosis and beta-thalassemia major: role of the IGF-I/IGFBP-III axis. J Endocrinol Invest 2002;25:338-344.

13. Morabito N, Russo GT, Gaudio A, Lasco A, Catalano A, Morini E, Franchina F, Maisano D, La Rosa M, Plota M, Crifò A, Meo A, Frisina $\mathrm{N}$. The "lively" cytokines network in beta-Thalassemia Major-related osteoporosis. Bone 2007;40:1588-1594.

14. Bordat C, Constans A, Bouet O, Blanc I, Trubert CL, Girot R, Cournot G. Iron distribution in thalassemic bone by energy-loss spectroscopy and electron spectroscopic imaging. Calcif Tissue Int 1993;53:29-37.

15. Baldini M, Forti S, Marcon A, Ulivieri FM, Orsatti A, Tampieri B, Airaghi L, Zanaboni L, Cappellini MD. Endocrine and bone disease in appropriately treated adult patients with beta thalassemia major. Ann Hematol 2010;89:1207-1213

16. Chan YL, Pang LM, Chik KW, Cheng JC, Li CK. Patterns of bone diseases in transfusion-dependent homozygous thalassaemia major: predominance of osteoporosis and desferrioxamine-induced bone dysplasia. Pediatr Radiol 2002;32:492-497.

17. Di Stefano M, Chiabotto P, Roggia C, Garofalo F, Lala R, Piga A, Isaia GC. Bone mass and metabolism in thalassemic children and adolescents treated with different iron-chelating drugs. J Bone Miner Metab 2004;22:53-57.

18. Dandona P, Menon RK, Houlder S, Thomas M, Hoffbrand AV, Flynn DM. Serum 1,25 dihydroxyvitamin D and osteocalcin concentrations in thalassemia major. Arch Dis Child 1987;62:474-477.

19. NIH Consensus Development Panel on Osteoporosis Prevention, Diagnosis, and Therapy. Osteoporosis prevention, diagnosis, and therapy. JAMA 2001;285:785-795.

20. No authors listed. Assessment of fracture risk and its application to screening for postmenopausal osteoporosis. World Health Organ Tech Rep Ser 1994;843:1-129.

21. Kalkwarf HJ, Abrams SA, DiMeglio LA, Koo WW, Specker BL, Weiler H; International Society for Clinial Densitometry. Bone densitometry in infants and young children: the 2013 ISCD Pediatric Official Positions J Clin Densitom 2014;17:243-257.

22. Lasco A, Morabito N, Gaudio A, Buemi M, Wasniewska M, Frisina N Effects of hormonal replacement therapy on bone metabolism in young adults with beta-thalassemia major. Osteoporos Int 2001;12:570-575.

23. Mahachoklertwattana P, Sirikulchayanonta V, Chuansumrit A, Karnsombat P, Choubtum L, Sriphrapradang A, Domrongkitchaiporn $\mathrm{S}$, Sirisriro R, Rajatanavin R. Bone histomorphometry in children and adolescents with beta-thalassemia disease: iron-associated focal osteomalacia. J Clin Endocrinol Metab 2003;88:3966-3972.

24. Kröger H, Kotaniemi A, Kröger L, Alhava E. Development of bone mass and bone density of the spine and the neck: a prospective study of 65 children and adolescents. Bone Miner 1993;17:75-85

25. Vogiatzi MG, Autio KA, Mait JE, Schneider R, Lesser M, Giardina PJ. Low bone mineral density in adolescents with beta-thalassemia. Ann N Y Acad Sci 2005; 1054:462-466.

26. Vogiatzi MG, Macklin EA, Fung EB, Cheung AM, Vichinsky E, Olivieri N, Kirby M, Kwiatkowski JL, Cunningham M, Holm IA, Lane J, Schneider R, Fleisher M, Grady RW, Peterson CC, Giardina PJ; Thalassemia Clinical Research Network. Bone disease in thalassemia: a frequent and still unresolved problem. J Bone Miner Res 2009;24:543-557.

27. Pirinççioğlu AG, Akpolat V, Köksal O, Haspolat K, Söker M. Bone mineral density in children with beta-thalassemia major in Diyarbakir. Bone 2011:49:819-823.

28. Aslan I, Canatan D, Balta N, Kacar G, Dorak C, Ozsancak A, Oguz N, Cosan R. Bone mineral density in thalassemia major patients from antalya, Turkey. Int J Endocrinol 2012;2012:573298.

29. Izadyar S, Fazeli M, Izadyar M, Salamati P, Gholamrezanezhad A Bone mineral density in adult patients with major thalassaemia: our experience and a brief review of the literature. Endokrynol Pol 2012;63:264-269

30. Tzoulis P, Ang AL, Shah FT, Berovic M, Prescott E, Jones R, Barnard M Prevalence of low bone mass and vitamin D deficiency in $\beta$-thalassemia major. Hemoglobin. 2014;38:173-178

31. Fung EB, Harmatz PR, Milet M, Coates TD, Thompson AA, Ranalli M, Mignaca R, Scher C, Giardina P, Robertson S, Neumayr L, Vichinsky EP; Multi-Center Iron Overload Study Group. Fracture prevalence and relationship to endocrinopathy in iron overloaded patients with sickle cell disease and thalassemia. Bone 2008;43:162-168. 
32. Exarchou E, Politou C, Vretou E, Pasparakis D, Madessis G, Caramerou A. Fractures and epiphyseal deformities in beta-thalassemia. Clin Orthop Relat Res 1984;189:229-233.

33. Finsterbush A, Farber I, Mogle P, Goldfarb A. Fracture patterns in thalassemia. Clin Orthop Relat Res 1985;192:132-136.

34. Vogiatzi MG, Macklin EA, Fung EB, Vichinsky E, Olivieri N, Kwiatkowsk J, Cohen A, Neufeld E, Giardina PJ. Prevalence of fractures among the Thalassemia syndromes in North America. Bone 2006;38:571-575

35. Sutipornpalangkul W, Janechetsadatham Y, Siritanaratkul N, Harnroongroj T. Prevalence of fractures among Thais with thalassaemia syndromes. Singapore Med J 2010;51:81 7-821

36. Engkakul P, Mahachoklertwattana P, Jaovisidha S, Chuansumrit A, Poomthavorn P, Chitrapazt N, Chuncharunee S. Unrecognized vertebral fractures in adolescents and young adults with thalassemia syndromes. J Pediatr Hematol Oncol 2013;35:212-217

37. Dresner Pollack R, Rachmilewitz E, Blumenfeld A, Idelson M, Goldfarb AW. Bone mineral metabolism in adults with beta-thalassaemia major and intermedia. Br J Haematol 2000;111:902-907.

38. Voskaridou E, Kyrtsonis MC, Terpos E, Skordili M, Theodoropoulos I, Bergele A, Diamanti E, Kalovidouris A, Loutradi A, Loukopoulos D. Bone resorption is increased in young adults with thalassaemia major. Br J Haematol 2001;112:36-41.

39. Carmina E, Di Fede G, Napoli N, Renda G, Vitale G, Lo Pinto C, Bruno D, Malizia R, Rini GB. Hypogonadism and hormone replacement therapy on bone mass of adult women with thalassemia major. Calcif Tissue Int 2004;74:68-71.

40. De Vernejoul MC, Girot R, Gueris J, Cancela L, Bang S, Bielakoff J, Mautalen C, Goldberg D, Miravet L. Calcium phosphate metabolism and bone disease in patients with homozygous thalassemia. J Clin Endocrinol Metab 1982;54:276-281.

41. Voskaridou E, Terpos E, Spina G, Palermos J, Rahemtulla A, Loutradi A, Loukopoulos D. Pamidronate is an effective treatment for osteoporosis in patients with beta-thalassaemia. Br J Haematol 2003;123:730-737.

42. Morabito N, Gaudio A, Lasco A, Atteritano M, Pizzoleo MA, Cincotta M, La Rosa M, Guarino R, Meo A, Frisina N. Osteoprotegerin and RANKL in the pathogenesis of thalassemia-induced osteoporosis: new pieces of the puzzle. J Bone Miner Res 2004;19:722-727.

43. Simonet WS, Lacey DL, Dunstan CR, Kelley M, Chang MS, Lüthy R, Nguyen HQ, Wooden S, Bennett L, Boone T, Shimamoto G, DeRose M, Elliott R, Colombero A, Tan HL, Trail G, Sullivan J, Davy E, Bucay N, Renshaw-Gegg L, Hughes TM, Hill D, Pattison W, Campbell P, Sander S, Van G, Tarpley J, Derby P, Lee R, Boyle WJ. Osteoprotegerin: a novel secreted protein involved in the regulation of bone density. Cell 1997:89:309-319.

44. Manolagas SC, Jilka RL. Bone marrow, cytokines, and bone remodeling Emerging insights into the pathophysiology of osteoporosis. N Engl Med 1995:332:305-311

45. Pacifici R. Estrogen, cytokines, and pathogenesis of postmenopausal osteoporosis. J Bone Miner Res 1996;11:1043-1051.

46. Lee SK, Gardner AE, Kalinowski JF, Jastrzebski SL, Lorenzo JA. RANKLstimulated osteoclast-like cell formation in vitro is partially dependent on endogenous interleukin-1 production. Bone 2006;38:678-685

47. Jimi E, Nakamura I, Ikebe T, Akiyama S, Takahashi N, Suda T. Activation of NF-kB is involved in the survival of osteoclast promoted by interleukin-1. J Biol Chem 1998;273:8799-8805.

48. Morabito N, Catalano A, Gaudio A, Morini E, Bruno LM, Basile G, Tsiantouli E, Bellone F, Agostino RM, Piraino B, La Rosa MA, Salpietro C, Lasco A. Effects of strontium ranelate on bone mass and bone turnover in women with thalassemia major-related osteoporosis. J Bone Miner Metab 2016;34:540-546
49. Voskaridou E, Christoulas D, Plata E, Bratengeier C, Anastasilakis AD, Komninaka V, Kaliontzi D, Gkotzamanidou M, Polyzos SA, Dimopoulou M, Terpos E. High circulating sclerostin is present in patients with thalassemia-associated osteoporosis and correlates with bone mineral density. Horm Metab Res 2012;44:909-913.

50. Cazzola M, De Stefano P, Ponchio L, Locatelli F, Beguin Y, Dessi C, Barella S, Cao A, Galanello R. Relationship between transfusion regimen and suppression of erythropoiesis in beta-thalassaemia major. Br J Haematol 1995;89:473-478.

51. Ma ES, Lam KK, Chan AY, Ha SY, Au WY, Chan LC. Transferrin receptor-2 polymorphisms and iron overload in transfusion independent $\beta$-thalassemia intermedia. Haematologica 2003;88:345-346.

52. Manolagas SC, Jilka RL. Bone marrow, cytokines, and bone remodeling Emerging insights into the pathophysiology of osteoporosis. N Engl J Med 1995;332:305-311

53. No authors listed. Multicentre study on prevalence of endocrine complications in thalassaemia major. Italian Working Group on Endocrine Complications in Non-endocrine Diseases. Clin Endocrinal (Oxf) 1995;42:581-586.

54. Borgna-Pignatti C, Marsella M. Iron Chelation in Thalassemia Major Clin Ther 2015;37:2866-2877.

55. De Sanctis V, Vullo C, Katz M, Wonke B, Hoffbrand VA, Di Palma A, Bagni B. Endocrine complications in thalassemia major. Prog Clin Biol Res 1989;309:77-83.

56. Shalitin S, Carmi D, Weintrob N, Phillip M, Miskin H, Kornreich L, Zilber R, Yaniv I, Tamary H. Serum ferritin level as a predictor of impaired growth and puberty in thalassemia major patients. Eur J Haematol 2005:74:93-100.

57. Kwan EY, Lee AC, Li AM, Tam SC, Chan CF, Lau YL, Low LC. A crosssectional study of growth, puberty and endocrine function in patients with thalassaemia major in Hong Kong. J Paediatr Child Health 1995;31:83-87.

58. Suda K. Hemosiderin deposition in the pancreas. Arch Pathol Lab Med 1985;109:996-999.

59. Berkovitch M, Bistritzer T, Milone SD, Perlman K, Kucharczyk W, Olivieri NF. Iron deposition in the anterior pituitary in homozygous beta-thalassemia: MRI evaluation and correlation with gonadal function. J Pediatr Endocrinol Metab 2000;13:179-184

60. Wonke B. Clinical management of beta-thalassemia major. Semin Hematol 2001;38:350-359

61. Riggs BL. The mechanisms of estrogen regulation of bone resorption. J Clin Invest 2000:106:1203-1204

62. Hofbauer LC, Khosla S. Androgen effects on bone metabolism: recent progress and controversies. Eur J Endocrinol 1999;140:271-286.

63. Compston JE. Sex steroids and bone. Physiol Rev 2001;81:419-447.

64. Geusens PP, Boonen S. Osteoporosis and the growth hormone-insulinlike growth factor axis. Horm Res 2002;58(Suppl 3):49-55.

65. Rucker D, Ezzat S, Diamandi A, Khosravi J, Hanley DA. IGF-I and testosterone levels as predictors of bone mineral density in healthy, community-dwelling men. Clin Endocrinol (Oxf) 2004;60:491-499.

66. Danesi L, Scacchi M, De Martin M, Dubini A, Massaro P, Majolo AT, Cavagnini F, Polli EE. Evaluation of hypothalamic-pituitary function in patients with thalassemia major. J Endocrinol Invest 1992;15:177-184

67. Shehadeh N, Hazani A, Rudolf MC, Peleg I, Benderly A, Hochberg Z. Neurosecretory dysfuntion of growth hormone secretion in thalassemia major. Acta Paediatr Scand 1990;79:790-795.

68. Katzos G, Harsoulis F, Papadopoulou M, Athanasiou M, Sava K. Circadian growth hormone secretion in short multitrasfused prepubertal children with thalassemia major. Eur J Pediatr 1995;154:445-449. 
69. Chatterjee R, Katz M, Cox T, Bantock H. Evaluation of growth hormone in thalassemic boys with failed puberty: spontaneous versus provoking test. Eur J Pediatr 1993;152:721-726.

70. Chrysis DC, Alexandrides TK, Koromantzou E, Georgopoulos N, Vassilakos P, Kiess W, Kratsch J, Beratis NG, Spiliotis BE. Novel application of IGF-1 and IGFBP-3 generation tests in the diagnosis of growth hormone axis disturbances in children with beta-thalassaemia. Clin Endocrinol (Oxf) 2001;54:253-259.

71. Voskaridou E, Terpos E. New insights into the pathophysiology and management of ossteoporosis in patients with beta thalasaemia. Br J Haematol 2004;127:127-139

72. De Sanctis V, Pinamonti A, Di Palma A, Sprocati M, Atti G, Gamberini MR, Vullo C. Growth and development in thalassaemia major patients with severe bone lesions due to desferrioxamine. Eur J Pediatr 1996;155:368-372

73. Wonke B, Jensen C, Hanslip JJ, Prescott E, Lalloz M, Layton M, Erten S, Tuck S, Agnew JE, Raja K, Davies K, Hoffbrand AV. Genetic and acquired predisposing factors and treatment of osteoporosis in thalassaemia major. J Pediatr Endocrinol Metab 1998;11(Suppl 3):795-801.

74. Perrotta S, Cappellini MD, Bertoldo F, Servedio V, Iolascon G, D’Agruma L, Gasparini P, Siciliani MC, Iolascon A. Osteoporosis in betathalassaemia major patients: analysis of the genetic background. $\mathrm{Br} \mathrm{J}$ Haematol 2000:111:461-466.

75. Ferrara M, Matarese SM, Francese M, Borrelli B, Coppola A, Coppola L, Esposito L. Effect of VDR polymorphisms on growth and bone mineral density in homozygous beta thalassaemia. Br J Haematol 2002;11 7:436-440.

76. Gaudio A, Morabito N, Xourafa A, Currò M, Caccamo D, Ferlazzo N, Macrì I, La Rosa MA, Meo A, Ientile R. Role of genetic pattern on bone mineral density in thalassemic patients. Clin Biochem 2010;43:805-807.

77. Dimitriadou M, Christoforidis A, Fidani L, Economou M, Vlachaki E, Athanassiou-Metaxa M, Katzos G. A 2-year prospective densitometric study on the influence of Fok-I gene polymorphism in young patients with thalassaemia major. Osteoporos Int 2016;27:781-788. 